\title{
DOMESTIC AND FOBEIGN INVESTMENT 2019 IN ADVANCED ECONOMIES. THE ROLE OF INDUSTRY INTEGRATION
}

Teresa Sastre and Laura heras Recuero.

Documentos de Trabajo. N. 1933

BANCO DE ESPANAA

\author{
Eurosistema
}


DOMESTIC AND FOREIGN INVESTMENT IN ADVANCED ECONOMIES.

THE ROLE OF INDUSTRY INTEGRATION 
DOMESTIC AND FOREIGN INVESTMENT IN ADVANCED

ECONOMIES. THE ROLE OF INDUSTRY INTEGRATION $\left.{ }^{*}\right)$

Teresa Sastre and Laura Heras Recuero

BANCO DE ESPAÑA

${ }^{*}$ ) We thank the participants at the European Network for Research on Investment Workshop organized by the European Investment Bank (Luxembourg, 2018) and the internal seminar at Banco de España (March 2019) for helpful comments and suggestions. The views expressed in this paper are those of the authors and do therefore not necessarily reflect the views of the Banco de España or the Eurosystem. 
The Working Paper Series seeks to disseminate original research in economics and finance. All papers have been anonymously refereed. By publishing these papers, the Banco de España aims to contribute to economic analysis and, in particular, to knowledge of the Spanish economy and its international environment.

The opinions and analyses in the Working Paper Series are the responsibility of the authors and, therefore, do not necessarily coincide with those of the Banco de España or the Eurosystem.

The Banco de España disseminates its main reports and most of its publications via the Internet at the following website: http://www.bde.es.

Reproduction for educational and non-commercial purposes is permitted provided that the source is acknowledged.

C BANCO DE ESPAÑA, Madrid, 2019

ISSN: 1579-8666 (on line) 


\section{Abstract}

Previous research using country or firm data has been inconclusive on the sign of the relation between domestic and foreign investment. Though several hypotheses have been formulated, the factors determining the sign of this relationship are not clearly identified yet. In this paper we explore the role of industry integration in determining the relation between outward foreign direct investment (FDI) and domestic investment by using disaggregated data at the industry level and several indicators of industry integration. The proportion of intangible investment is used as a proxy of horizontal integration and several measures of participation in Global Value Chains (GVCs) as proxies of vertical integration. The empirical results confirm that the relationship between outward FDI and domestic investment is very varied and differs across industries and countries. That relation is positive (complementary) for those industries with low intensity in intangible investment and high forward integration in GVCs -two features of vertically integrated industries- and becomes negative for those industries with high intangible investment (usually more horizontally integrated).

Keywords: investment, foreign direct investment, vertical and horizontal integration, global value chains.

JEL classification: E22, F21. 


\section{Resumen}

Los análisis con datos a nivel de empresa o de país no han alcanzado resultados concluyentes sobre el signo de la relación entre la inversión de las empresas en el exterior y la inversión en el país de origen de las mismas. Aunque se han formulado varias hipótesis, los factores que determinan el signo de esta relación aún no han sido claramente identificados. En este trabajo exploramos si el tipo de integración de la industria determina, de algún modo, la relación entre las salidas de inversión extranjera directa (IED) y la inversión doméstica. Para ello se utilizan datos desagregados de sectores productivos y varios indicadores del tipo de integración industrial. La intensidad en activos intangibles se emplea como proxy del grado de integración horizontal y varios indicadores de participación en las cadenas globales de valor (CGV) para caracterizar las industrias con mayor grado de integración vertical. Los resultados empíricos confirman que la relación entre las salidas de IED y la inversión doméstica es heterogénea entre sectores y difiere entre países. La relación es positiva (complementaria) en aquellos sectores con baja intensidad de inversión en intangibles y en los de elevada integración en cadenas de valor con predominio de conexiones forward (hacia el final de la cadena de producción) - dos características de las industrias integradas verticalmente-. En cambio, resulta negativa en aquellas industrias con un alto grado de inversión en intangibles, característica más propia de industrias integradas horizontalmente.

Palabras clave: inversión, inversión extranjera directa, integración vertical y horizontal, cadenas globales de valor.

Códigos JEL: E22, F21. 


\section{Introduction}

In the last two decades, the global economy have lived a growing process of internationalisation of firms, while a large number of emerging countries have become part of the global value chain. Both processes have been driven by technological developments in the area of communication networks and information (since these developments have substantially reduced costs), by the liberalisation of capital movements in various regions and by the signing of a number of trade and economic integration agreements (such as the creation of the euro area and the European Union, and their enlargement to Eastern European countries, or China joining the World Trade Organization). All of these factors have contributed to boost the development of global production chains, a notable increase in cross-border trade and, in general, the globalisation of economic activity. As a result of this process a growing proportion of world production and investment has been located in emerging economies, driven by expanding markets and lower production costs. According to UNCTAD, in 1990 the foreign direct investment inflows to developing countries accounted for $16.9 \%$ of total inflows while in 2017 it was $50.2 \%$.

The internationalisation of production, associated to the expansion of foreign direct investment, has frequently caused political concerns regarding the effects on home economies. The fear of either potential job losses or a negative impact on home wages, or both, has been an argument usually used against the international expansion of companies that were old-time domestic. Examining the relation between the investments that domestic companies make abroad and the one generated within the country comes up as a key question in this scenario. The increasing foreign direct investment to emerging economies has also been pointed out as a factor behind the slowdown in the recovery of domestic investment in advanced economics in the aftermath of the financial crisis. Moreover, a potential negative effect of outward FDI on domestic investment might also be detrimental to productivity developments and, in some cases, hamper macroeconomic stability by exacerbating external imbalances in some advanced economies which hold large current account surpluses.

In the event that a multinational firm did not easily increase its worldwide production in response to rising costs of financial resources, FDI and domestic investment would compete for financial resources. Then, greater foreign business activity would come at the cost of reduced domestic activity thus prompting a negative correlation between them ${ }^{1}$. There is, however, an alternative view suggesting that growing foreign investment may increase domestic activity by improving profitability and competitiveness of domestic operations of global firms. In the case that investment abroad raised the return of domestic production, for example, because that investment provided for inputs obtained at low cost, this might positively affect domestic factor demand (labour and capital) and domestic output. Therefore, whether domestic and outward investment are positively related (complementary) or negatively (substitutes) seems to be a matter for empirical testing.

\footnotetext{
${ }^{1}$ See Stevens and Lipsey (1992).
} 
The empirical literature addressing whether outward FDI influences domestic investment positively (complementarity) or negatively (substitution effect) is generally based on the theory of comparative advantage (factor endowments and origin and destination country characteristics) and on the transaction costs paradigm. Countries where labour is relatively abundant will tend to attract foreign investment from firms seeking labour cost savings. In the last two decades, cross-country differences in relative factor abundance have given rise to networks of subsidiaries providing inputs to their parent firms, a process known as global value chains. These global networks are increasingly associated with foreign direct investment flows and with an increasing volume of trade in intermediate goods which reflect intra-firm transactions with production stages located in different countries. However, several empirical analysis $^{2}$ have shown that intra-firm trade occurs mostly between capital abundant countries. The second paradigm used to analyse multinationals decisions to invest abroad is the transaction costs paradigm. For those firms seeking access to foreign markets the existence of barriers to trade (tariffs, non-tariff barriers), transport costs and oversight and coordination costs are factors that have a bearing on how they decide to serve foreign markets: either investing in domestic plants that export their production or establishing a foreign affiliate ${ }^{3}$, or other ways to locate production abroad (outsourcing, licensing,...). Advances in communication technology, trade liberalisation and trade agreements have decreased both international trade costs (transport costs, tariffs and other trade barriers) and oversight and coordination costs, thus lowering offshoring and foreign outsourcing costs. This, together with the liberalisation of capital flows, has modified the previous balance between barriers to trade and coordination costs, giving rise to an unprecedented expansion of foreign direct investment. Finally, individual firms' characteristics and the nature of the industry in which they operate (type of economies of scale, substitutability among inputs,...) also determine multinational choices for the organization of production, including its cross-country geographical organisation ${ }^{4}$.

Though most multinationals adopt complex integration strategies in the geographical organisation of their production process, the literature has traditionally distinguished two main polar cases: vertical and horizontal integration of the production process across countries. Vertical investment takes place when multi-plants fragment production into different stages located in different areas (frequently taking advantage of differences in factor prices across countries) while horizontal investment is adopted by multi-plant firms that produce similar goods or services in different countries. Where production is fragmented into stages distributed across different geographical areas (vertical integration), occasionally structured in the form of value chains, investment in the different areas will be complementary, either as a simultaneous response to changes in the determinants of the firm's global investment or because production abroad requires inputs produced by the parents or vice versa. Conversely, if the internationalisation is mainly based on plants in different locations which replicate the same type of productive process (horizontal integration), — possibly as a result of a decision

\footnotetext{
${ }^{2}$ See, for instance, Antras (2003).

${ }^{3}$ In Helpman, Melitz and Yeaple (2004) firms invest abroad when the gains from avoiding trade costs outweigh the costs of maintaining capacity in multiple markets.

${ }^{4}$ See Helpman (2006).
} 
to replace exports to these markets with local production, in order to save on transport costs, benefit from potential labour cost advantages, remove the impact of tariff and non-tariff barriers-, foreign investment would be replacing domestic investment. The knowledge-capital model of the multinational enterprise provides a synthesis of theory in which both types of FDI, vertical and horizontal, can emerge endogenously, depending on characteristics of the home and host country (relative size and factor endowments) and trade costs ${ }^{5}$.

Most empirical studies can be grouped into two strands. The first one, that has approached the topic by using aggregated country-data in their analysis, reached mixed conclusions. Under the hypothesis that FDI and domestic investment compete for financial resources that have a rising cost, a substitutionary relationship can be expected between them. This hypothesis was supported by the first empirical studies on this relationship based on OECD country data (Feldstein, 1995; Desai, Foley and Hines Jr., 2005) and more recent analyses based on a wider dataset including emerging economies (Al-Sadig, 2013). However, firms operating in several countries can access financial resources in different local markets and redistribute them among the group companies according to their objectives. There may also be that the relationship between domestic and foreign investment is different in the short and the long run. At the beginning, when companies decide to move some production stages abroad, a substitution effect may be expected. Once that step is completed the response to changes in the determinants of firm's investment may likely have the same sign across the production stages, due to the inputs required by the foreign affiliate or by the parent company. Thus time series evidence for specific countries suggests a positive (complementary) relation between outward FDI and domestic investment in the long run in Australia and the US, although in Germany a substitution effect is obtained in the long run (Faeth, 2006; Herzet and Schrooten, 2008). The fact that the international expansion of firms does not follow a homogenous pattern but is the outcome of different strategies adopted by multinational firms might be one reason why country evidence offers these mixed results.

A more granular approach is followed by a second strand of the literature that aims to account for this diversity by using firm level data. Several studies have examined the relation between foreign and domestic investment by using data from US multinational firms. This is the case of Stevens and Lipsey (1992), who found a negative relation between FDI and investment in home economies on five of the seven US multinational firms that they analysed. On the contrary, Desai, Foley and Hines Jr. (2005) obtained a positive relation between foreign and domestic investment, since firms that invest more abroad also invest more in the US. In the case of Japanese multinational firms, Belderbos et al. (2013) found some substitution of domestic investment for foreign one. Barba Navaretti et al. (2010) also examine the impact of outward investment to cheap labour countries on home activities of French and Italian firms that turn multinational. They found no evidence of a negative effect of outward investment due to the geographical fragmentation of production and, in the case of Italian firms, foreign investment even enhance the efficiency of domestic activities in the long term, with a positive

\footnotetext{
${ }^{5}$ Markusen et al. (1996), Carr et al. (2001).
} 
effect on output and employment. Hence the empirical evidence at both macro and micro level does not clearly indentify those country or firm characteristics determining the type of foreign investment of multinational firms.

In this paper we explore a different approach based on insights from Helpman (2006), who points to the role of multinational choices regarding the organization of the production process (including the cross-country geographical organisation) to understand trade and investment patterns across national borders, and Helpman et al. (2004) that underline the need to give an account of cross-industry differences to understand companies' decision to invest abroad. This last suggestion is also consistent with the findings by Antras et al (2012) that the characterisation of different types of vertical integration tends to be stable within industries and across countries. Then a plausible assumption to characterize the multinational production process is that the way firms organize their production across countries is not only determined by home and host country comparative advantage and trade costs but is also linked to industry characteristics related to their production function (i.e. how inputs are combined to produce output). For that reason we use data disaggregated at the industry level trying to capture features such as how labour intensive the production process is in each industry, whether high-skilled workers are needed, the intensity in knowledge-based capital or other processes that can be used in many plants at the same time or whether more tangible inputs are needed. By assuming that these differences have a bearing on the type of industry integration (vertical or horizontal), we aim at identifying vertical and horizontal FDI from cross-industry differences in their production function, instead of using market conditions in home and host countries, as suggested by most previously mentioned analyses.

The study by Arndt et al. (2010) argue that industry-level data is more appropriate to assess the impact of FDI on domestic investment than country or firm-level data, though their argument is different to ours. Braunerhjelm (2005) also stresses the relevance of industry characteristics to appropriately capture the impact of investing abroad on investment in home economies. The analysis developed by Geishecker and Görg (2005) for a wide range of German industries is also closely related to our identifying strategy. They found that the link between outward FDI and domestic investment may differs across industries. In particular, they concluded a predominant vertical FDI component within manufacturing while FDI would be mainly horizontal in service industries. By using an industry-level approach in a sample of advanced economies -identifying industries where the predominant production process is either vertically or horizontally organised-, we think the sign and magnitude of the relationship between domestic and foreign investment may be captured more accurately than with country data. If the way firms organize their production were associated to industry characteristics, the effect of FDI on domestic aggregate investment would be determined by the industry distribution among vertical and horizontal types, i.e. the productive structure in home economies. This could help to understand that the FDI effect may be different across countries with similar characteristics (size, factor endowments, trade costs) and why country studies have been inconclusive regarding the relationship between foreign and domestic investment. 
To identify the type of production organization predominant in each industry we use several indicators of vertical and horizontal integration. Usual indicators of participation in global value chains are used as proxies of vertical integration, as well as two alternative ones aiming at overcoming some measurement problems pointed out in the recent literature. The two last ones are built on the proposals by Wang et al (2017). Finally, the share of intangible investment is used as a proxy of the degree of horizontal integration in each industry, following a long tradition in industrial organization studies.

\section{Empirical model and data}

In order to analyse the type of relationship between domestic and foreign direct investment advanced economies we estimate an equation for gross capital formation with industry-level data. The specification is based on the neoclassical theory framework where the user cost of capital plays a prominent role (Jorgenson, 1963). The long run desired capital stock $(k *)$ depends on demand expectations - proxied by output $(y)$ - and the real user cost of capital $(u c)$, which is a function of: the relative price of investment to output $(p K / p Y)$, the real cost of finance $(\rho)$, the depreciation rate $(\delta)$, the tax rate $(t)^{6}$ and the change of the relative price of investment to output $(\pi)$, which captures expected capital gains /losses.

$$
\begin{gathered}
u c \cong \frac{p^{K}}{p^{Y}}(\rho+\delta-\pi) \frac{1}{(1-t)} \\
k^{*}=\gamma_{1} * y+\gamma_{2} * u c
\end{gathered}
$$

Lowercase letters indicate logarithm of variables. Firms bring the current capital stock into line with its desired level by adjusting the level of gross investment $(I)$.

$$
K_{t+1}=(1-\delta) K_{t}+I_{t}
$$

Several assumptions ${ }^{7}$ yield a link between investment and capital that allow to rewrite the expression for the desired capital in terms of gross investment and a lag polynomial structure applied to investment and the other variables in expression (1).

$$
\alpha(L) \triangle i=\beta_{1}(L) \triangle y+\beta_{2}(L) \triangle u c
$$

The simplified notation for lag polynomials stands for a weighted average of past values of the variables:

$$
\alpha(L) \triangle x=\alpha_{0} \triangle x_{t}+\alpha_{1} \triangle x_{t-1}+\alpha_{2} \triangle x_{t-2}+\ldots
$$

\footnotetext{
${ }^{6}$ The tax adjustment in the user cost of capital should take into account both the effective rate and tax depreciation allowances.

${ }^{7}$ By assuming that net investment is a distributed lag process of changes in the desired capital stock (partial adjustment mechanism due to adjustment costs) and that capital stock and output grow at the same constant rate in the steady state (Bean, 1981), the desired capital stock can be replaced by an expression in terms of gross investment and other variables with a lag polynomial structure.
} 
The long run elasticity of investment to output is given by the ratio of polynomials $\beta_{1}(L) / \alpha(L)$ for $\mathrm{L}=1$ and is expected to be positive and close to unity, while the elasticity of investment to user cost is $\beta_{2}(L) / \alpha(L)$ and it is expected to be negative. Expression (3) provides the basic specification we use to test whether outward foreign direct investment is complementary to domestic investment or there is a substitution effect between them.

Our main hypothesis is that the sign of this relationship is related to the type of industry integration: fragmented into stages distributed across different geographical areas (vertical integration) or based on plants in different geographical locations which replicate the same type of productive process (horizontal integration). In this sense, it needs to be pointed out that there are no pure horizontally or vertically integrated industries but both types of integration are frequently combined across the production process. Furthermore, the type of integration is determined to a large extent by characteristics of the production technology, thus linked to industry characteristics. Therefore, our empirical strategy is based on using data disaggregated at the industry-level and identifying industries where the predominant production process is either vertically or horizontally organised.

The empirical model we estimate is a panel data model as follows:

$$
\alpha(L) \triangle i_{i t}=\beta_{1}(L) \triangle y_{i t}+\beta_{2}(L) \triangle u c_{i t}+\beta_{3}(L) f d i_{i t}+\beta_{4}(L)(f d i * I n)_{i t}+\epsilon_{i t}
$$

The dependent variable $\triangle i_{i}$ is the rate of change of real gross capital formation in industry $i$. The variable $f d i$ is defined as the ratio of outward foreign direct investment to output in each industry $i$ and $I n$ stands for an indicator variable of vertical / horizontal industry integration (see table 1 in the Appendix). Several indicators of vertically-organised industries have been proposed in the empirical literature, such as variables proxying the degree of integration in global value chains obtained from the world input-output tables ${ }^{8}$. Other suggested indicators are the share of high-skilled workers or the intensity in knowledge-based capital. We build on those suggestions by using the industry intensity in intangible investment as an indicator of horizontal integration, which has long tradition in industrial organization studies ${ }^{9}$. Activities with a technological content linked to creativity and knowledge (intangible assets), that are usually used on a non-rival basis (they may be used simultaneously at several plants), tend to generate horizontally organised production structures ${ }^{10}$. Thus horizontally integrated industries are expected to show a high share of investment in intangible assets. On the other hand, in value chains and other vertically integrated industries most of the intermediate inputs are only used once by each plant along the different production stages. Certainly, intangible intensity does not provide a clear-cut identification of vertical and horizontal integration, but it shows to be helpful in identifying the predominant type of integration at the industry level. In this study intensity in intangibles is defined as the ratio of investment in intellectual prop-

\footnotetext{
${ }^{8}$ For instance, the World Input-Output Database or the WTO-OECD Trade in Value Added (TiVA) Database. ${ }^{9}$ See Perry (1989) for an overview of this literature. More recently, Braunerhjelm (2005) also used research and development as an integration indicator to conduct a similar exercise for industrial sectors in Sweden.

${ }^{10}$ See Williamson (1985).
} 
erty (research and development, databases, software and other intellectual property) to total gross investment. As shown in figure 1, in advanced economies the intangible median share ranks from almost zero in agriculture and accommodation and food services up to about $60 \%$ in information and communication and professional and technical activities.

As an alternative approach, we use several indicators of participation in global value chains as proxies of vertical integration. The first one is based on the idea proposed by Koopman et al (2010) that integrated forward and backward measures of vertical specialisation in one single indicator using value-added trade data. In this paper we use the sum of two vertical integration indicators (one forward and one backward) which are commonly used in the literature. The first one is the domestic value added embodied in foreign exports as share of gross exports, and the backward indicator is the foreign value added share of gross exports. These indicators are not free of problems when measuring global value chains participation, as it has been pointed out in more recent literature ${ }^{11}$. The solely focus on complex $\mathrm{GVCs}^{12}$ and the use of gross exports in the denominator have been highlighted as two of the main problems of those indicators. The first aspect leads to the exclusion of those GVCs involving only one cross-border trade transaction while the second one tends to overestimate the participation in GVCs in those industries where the level of direct exports is small. Therefore, to address these issues we construct two additional indicators of backward and forward participation based on those proposed by Wang et al (2017) by using variables from the OECD Trade in Value Added database. The forward participation indicator is defined as the ratio of exports of intermediates over value added and the backward indicator is obtained as the imports of intermediates over final production. It is worth mentioning that the correlation between these vertical integration variables and our indicator of horizontal integration is very close to zero. In practice, this means GVC indicators and intellectual property contain different information as expected, and when using them in an alternative way, it would be reassuring in case the results obtained with both of them are mutually consistent.

Equation (4) also includes the controls of a basic investment equation, represented by expression (3): the rate of change of output in industry $i\left(\triangle y_{i}\right)$ and the rate of change of user cost of capital in industry $\left(\triangle u c_{i}\right)$. The latter is defined as in expression (1) assuming the industry depreciation rate keeps fairly stable over time. The tax component considered in the user cost proxies very roghtly the actual effect of taxation on this cost (due to data availabity issues ${ }^{13}$ ). The error term in equation (4) does not include industry-specific fixed effects that could affect investment levels since the equation is specified in first differences and they are wiped out.

This study employs a dataset that contains information for 19 productive sectors (ISIC 4, highest level) -including both industrial and service sectors- in 19 advanced economies over

\footnotetext{
${ }^{11}$ Wang et al (2017).

${ }^{12}$ Complex value chains are those which involve at least two cross-border trade transactions.

${ }^{13}$ Information on tax depreciation allowances at industry-level seems not to be available. Therefore, only country corporate tax rates were considered to obtain the user cost variable.
} 
Figure 1: Horizontal and vertical integration indicators (a) (b)

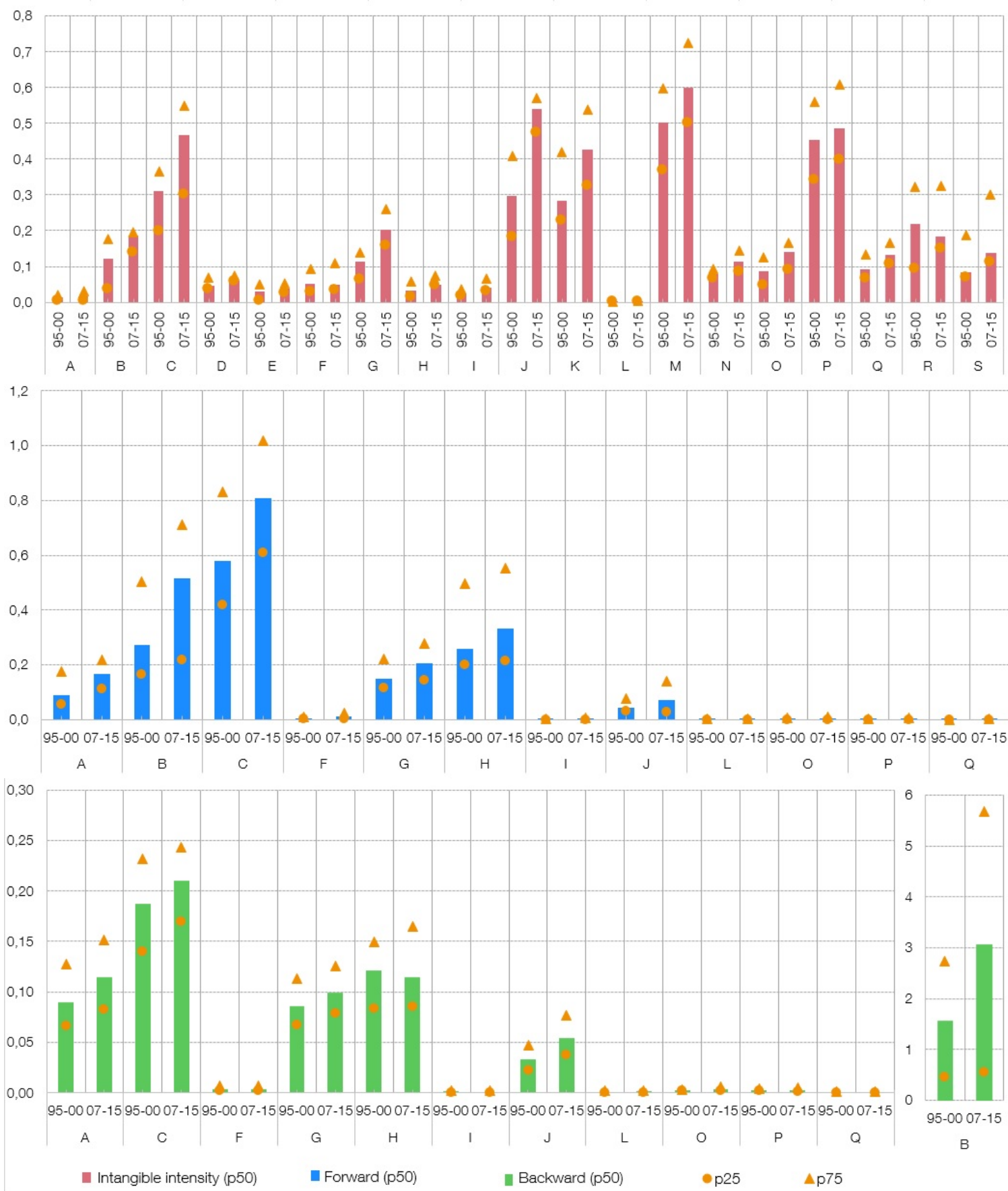

Source: Eurostat, OECD

(a) Horizontal integration indicator is the Intellectual property investment as a proportion of total investment (intangible intensity), the forward integration indicator is defined as the gross exports of intermediates on value added and the backward integration indicator is defined as the imports of intermediates on production.

(b) A: agriculture; B: mining; C: manufacturing industry; D: electricity, gas; E: water supply; F: construction; G: retail; H: transport; I: hotels, restaurants; J: information, communication; K: financial services; L: real estate actitivities; M: professional services; N: administrative activities; O: public administration; P: education; Q: health, social work; R: arts, entertainment; S: other service activities.

the period 1995-2014. Data were obtained from national statistical offices, OECD Structural Analysis (STAN) Database, OECD Trade in Value Added (TiVa) Database and Eurostat. The main variables come from ESA 2010 national accounts: industry gross capital formation, gross value added, investment and output deflators, labour compensation of employees and 
investment in intellectual property. Industry outward foreign direct investment ${ }^{14}$, country interest rates and vertical integration indicators were obtained from OECD databases while effective tax rates are those of the Oxford University Centre for Business Taxation. All data are at yearly frequency.

\section{Main empirical results}

\section{Horizontal integration}

Table 1 shows the main results of estimating equation (4) when the horizontal integration indicator is considered. In the first two columns the specification includes FDI outflows without the horizontal integration indicator. The first column corresponds to our basic specification while column (2) incorporates country fixed effects to give account of possible unobserved time-invariant differences across countries such as labour market regulation or institutional framework that could impact industry investment rates of change. Column (3) has the same specification as column (2) with an additional variable: the interaction of foreign investment with the industry intangible intensity which is our proposed horizontal integration indicator. The three first columns were estimated by ordinary least squares (OLS). The coefficient on value added is positive and the one on user cost is negative as expected according to the neoclassical model. Both are statistically significant at 1 percent level. In all specifications the estimated coefficient of FDI outflows is also significant and positive indicating that industrylevel domestic investment tends to grow while foreign direct investment abroad also increases, suggesting some source of complementarity between them. However, as reported in column (3) this complementarity is diminished in those industries with a high intangible share, the most prone to be horizontally integrated. Furthermore, if intangible intensity is high enough the link between domestic and foreign direct investment may become negative pointing to a substitution between them. Thus, the more horizontally integrated an industry is, their FDI outflows will usually be associated with lower domestic investment ${ }^{15}$.

Potential endogeneity issues due to the simultaneous determination of industry gross fixed investment and the user cost (that includes the relative price of capital) were partially addressed by including the user cost lagged one period in OLS estimations. There are, however, other sources of bias in these estimates like the correlation between output and investment and the two-way relationship between FDI and investment. Firms usually make simultaneous decisions about domestic and foreign investment. Those factors that lead firms to change investment in home countries (market or trade conditions, production costs, etc.) may also determine the rate of investment abroad.

\footnotetext{
${ }^{14}$ Data sources for FDI figures are harmonized balance of payments statistics according to the Fifth Manual of the Balance of Payments (BMD3).

${ }^{15}$ Different time-changing controls (country and time fixed effects, as well as country-time fixed effecs) were also tested. It was found that industry production and user cost of capital account for most of the changes in macroeconomic conditions, even common cross-country effects.
} 
Table 1: Horizontal integration estimations

\begin{tabular}{lccccc}
\hline & $(1)$ & $(2)$ & $(3)$ & $(4)$ & $(5)$ \\
\hline & OLS & OLS & OLS & IV & IV \\
\hline Dependent variable: D.log(Real investment) & & & & & \\
\hline D.log (Real investment (-1)) & -0.07 & -0.09 & -0.14 & -0.04 & $-0.12^{* *}$ \\
& $(0.06)$ & $(0.06)$ & $(0.09)$ & $(0.06)$ & $(0.06)$ \\
D.log (Value added) & $0.53^{* * *}$ & $0.50^{* * *}$ & $0.61^{* * *}$ & $1.34^{* * *}$ & $1.21^{* * *}$ \\
& $(0.15)$ & $(0.14)$ & $(0.19)$ & $(0.28)$ & $(0.26)$ \\
D.log (User cost of capital (-1)) & $-0.23^{* * *}$ & $-0.21^{* * *}$ & $-0.16^{* * *}$ & $-0.26^{* * *}$ & $-0.26^{* * *}$ \\
& $(0.05)$ & $(0.05)$ & $(0.05)$ & $(0.09)$ & $(0.09)$ \\
FDI (-1) & $0.03^{* * *}$ & $0.03^{* * *}$ & $0.19^{* * *}$ & $0.05^{* *}$ & $0.60^{* *}$ \\
& $(0.00)$ & $(0.01)$ & $(0.03)$ & $(0.02)$ & $(0.30)$ \\
FDI*Intelectual property & & & $-0.48^{* * *}$ & $-1.73^{* *}$ \\
& & & $(0.07)$ & $(0.88)$ \\
\hline Fixed effects & - & Country & Country & - & - \\
No. of Observations & 2494 & 2494 & 1847 & 2319 & 1719 \\
No. of Groups & 202 & 202 & 146 & 200 & 144 \\
2nd Order Correlation (p-value) & - & - & - & 0.96 & 0.77 \\
Hansen test (p-value) & - & - & - & 0.09 & 0.23 \\
\hline
\end{tabular}

Notes: All regressions include a constant term. Robust standard errors are shown in parenthesis and are clustered at the industry-level in the case of OLS estimations. Robust standard clustered errors corrected at country-industry level are reported in the case of IV estimations. Asterisks $(*, * *, * * *)$ indicate the level of significance $(10 \%, 5 \%, 1 \%)$ of coefficients. Equations (4) and (5) are estimated by using the system GMM procedure. Lagged investment, valued added and user cost of capital are instrumented with internal instruments (lags for the difference equation and differences for the level equation). FDI is instrumented with the fitted values of country regressions on the GDP of emerging economies and sector fixed effects.

To address the potential bias in OLS estimates due to these sources of endogeneity, equation (4) was also estimated by instrumental variable techniques. Two types of instruments were used: 1) a set of internal instruments based in Arellano and Bond's methodology ${ }^{16}$, that are used for output and user cost variables; 2) an instrument for FDI outflows obtained from a regression of this variable on GDP rate of change in several emerging economies areas (Latin America, East Asia and Eastern Europe) which are the main destination countries of foreign direct investment from advanced economies ${ }^{17}$. The regressions are country-dependent since cultural and historical reasons seem to favour FDI destinations that are different for each advanced economy. The fitted values of these regressions are used to compute the instrument for FDI in the estimations reported in columns (4) and (5) of table 1. This instrument is correlated with economic factors at the FDI destination countries and is much less likely to be correlated with factors underlying domestic investment.

The IV estimation technique used is the system-GMM estimator ${ }^{18}$ which has better properties than Arellano-Bond estimator when lagged levels are weak instruments. Sargan/Hansen test is performed to check for the validity of the over-identifying conditions implied by the use of the instruments in the estimations. In addition, we test for the absence of second order serial correlation of the differenced error term, an assumption needed to use Arellano-Bond and system-GMM estimators.

The results presented in columns (4) and (5) show that the coefficient of outward FDI is positive, as in OLS estimations, and its interaction with the intellectual property intensity keeps on being negative. The main changes are in the magnitude of the coefficients, consistent

\footnotetext{
${ }^{16}$ Appropriate lagged values (level) are used as instruments for the variables in an equation in differences.

${ }^{17}$ This idea is similar to the one addopted by Desai et al (2009) that obtain instruments in this way, with the difference that they use firm-level data.

${ }^{18}$ See Arellano (1995) and Blundell (1998).
} 
Figure 2: Effect of foreign investment on real investment growth (a)(b)

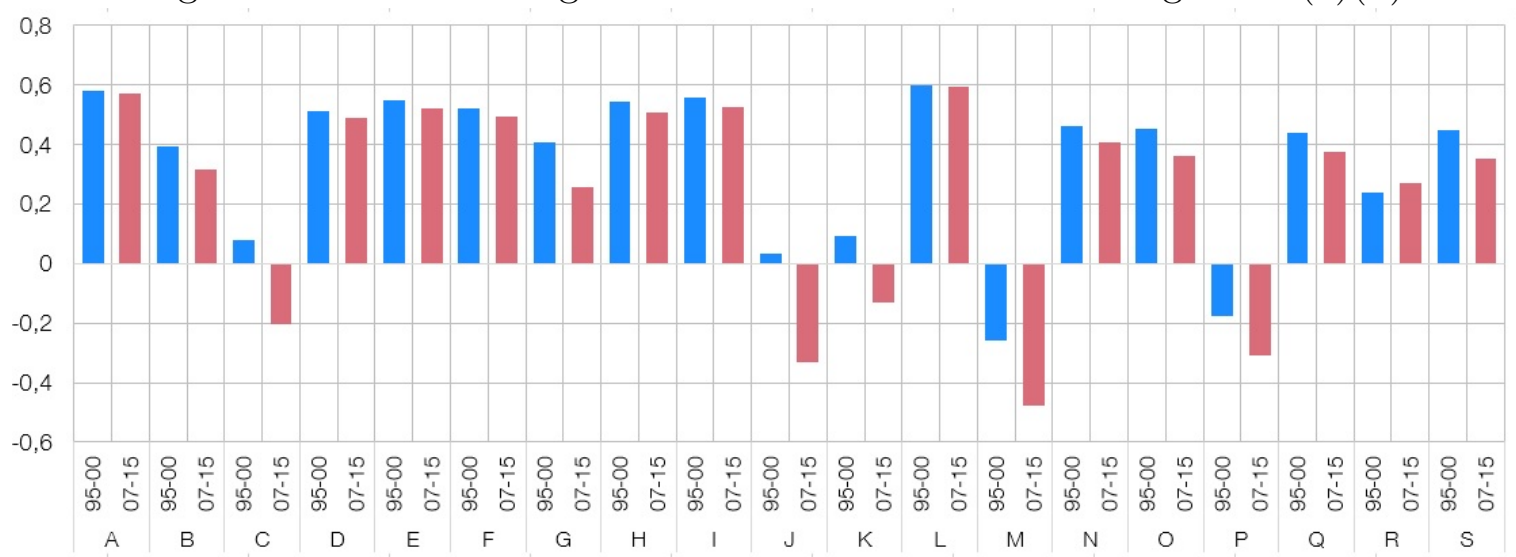

Source: Eurostat, OECD, own calculations.

(a) A: agriculture; B: mining; C: manufacturing industry; D: electricity, gas; E: water supply; F: construction; G: retail; H: transport; I: hotels, restaurants; J: information, communication; K: financial services; L: real estate actitivities; M: professional services; N: administrative activities; O: public administration; P: education; Q: health, social work; R: arts, entertainment; S: other service activities.

(b) Assessed at the median of intangible assets for each sector.

with an endogeneity bias of OLS estimates. The IV estimations are larger (in absolute value) both for the FDI terms and for the other variables in equation (4). According to these results, the effect of FDI on domestic investment is positive for those industries in which intensity in intangibles is low. If it is close to zero, the short run effect of a 1 percent point increase in FDI outflows (measured by the ratio of FDI flows to industry gross value added) is an increase of 0.60 percentage points in the change of rate of domestic investment, as reported in column (5). On the other hand, for those industries with high or increasing intensity in intangibles the impact on domestic investment will be lower and it depends on the intangible share of investment in each industry. In some cases it may become negative as shown in figure 2 that presents the net effect for the median of different industries. For example, in manufacturing FDI outflows would have had a negative impact on domestic investment in the period after the crisis, given the increase in intangible intensity. In professional services (M) the effect would have been negative for the whole period covered by our database. Furthermore, in those countries in which intensity in intellectual property is low (for example in manufacturing) the effect of FDI may still be positive in the latest years. The diversity of effects across industries may help explain why firm and country studies -that do not take into account the vertical /horizontal integration of production organisation- have been inconclusive regarding the relationship between foreign and domestic investment.

\section{Vertical integration}

Table 2 shows the results of estimating equation (4) using several indicators of vertical integration. The first column corresponds to the specification when the vertical integration indicator inspired by Koopman et al (2010) is interacted with the FDI variable. Column (2) displays the estimation with our proposed forward integration indicator and column (3) shows the results with our backward integration indicator, both based on Wang et al (2017). In all of them the coefficients of value added and user cost of capital remain with the expected 
sign and are significant at 1 percent level. The effect of FDI outflows on domestic investment is positive and, given the positive sign of the interaction with the forward indicator, it seems to be increasing with the degree of industry forward integration into value chains (column 2). This means that the relationship between outward FDI and domestic investment is complementary and stronger in those industries accounting for more forward linkages. The reason why forward linkages give rise to a positive correlation between investment abroad and domestic investment while this association is not found in industries with predominantly backward vertical integration is not clear. In the empirical literature the latter is frequently associated to a cost saving strategy of multinational firms which try to obtain parts and components in foreign countries with lower labour costs. Forward linkages are more commmon in market-seeking strategies when the international firm tries to get a closer relationship to customers by setting and affiliate or acquiring some local company. According to our results only this latter type of international linkages whould have a positive impact on domestic investment. Closely related results are obtained by Onaran et al. (2010). They find that FDI to high-wage countries is positively related to domestic investment due to market creation and market seeking effects, while FDI to low-wage countries, which is more likely to originate vertical backward integration, tends to substitute investment in home economies. On the other hand, as mentioned in section 1, Barba Navaretti et al. (2010) find that investments to cheap labour countries have no significant effect in home economies. In the case of the Koopman-type GVC indicator there would be no significant correlation with domestic investment.

The results of these IV estimations show that output and user cost variables remain significant and maintaining its sign. As in the previous results with the horizontal integration

Table 2: Vertical integration estimations

\begin{tabular}{|c|c|c|c|c|c|c|}
\hline & (1) & $(2)$ & $(3)$ & (4) & $(5)$ & (6) \\
\hline & OLS & OLS & OLS & IV & IV & IV \\
\hline \multicolumn{7}{|c|}{ Dependent variable: D.Real investment } \\
\hline D.log (Real investment (-1)) & $\begin{array}{l}-0.09 \\
(0.06)\end{array}$ & $\begin{array}{l}-0.03 \\
(0.03)\end{array}$ & $\begin{array}{l}-0.03 \\
(0.03)\end{array}$ & $\begin{array}{l}-0.05 \\
(0.05)\end{array}$ & $\begin{array}{c}-0.11^{*} \\
(0.06)\end{array}$ & $\begin{array}{l}-0.03 \\
(0.06)\end{array}$ \\
\hline D.log (Real investment $(-2))$ & & & & & $\begin{array}{c}-0.10^{* *} \\
(0.04)\end{array}$ & $\begin{array}{c}-0.10^{* *} \\
(0.04)\end{array}$ \\
\hline D.log (Value added) & $\begin{array}{c}0.49 * * * \\
(0.16)\end{array}$ & $\begin{array}{c}0.48^{* * *} \\
(0.17)\end{array}$ & $\begin{array}{c}0.47 * * * \\
(0.17)\end{array}$ & $\begin{array}{c}0.99 * * * \\
(0.17)\end{array}$ & $\begin{array}{c}0.80^{* * *} \\
(0.16)\end{array}$ & $\begin{array}{c}0.92^{* * *} \\
(0.21)\end{array}$ \\
\hline D.log (User cost of capital $(-1)$ ) & $\begin{array}{c}-0.20^{* * *} \\
(0.06)\end{array}$ & $\begin{array}{c}-0.19^{* * *} \\
(0.06)\end{array}$ & $\begin{array}{c}-0.19^{* * *} \\
(0.06)\end{array}$ & $\begin{array}{c}-0.18^{* *} \\
(0.08)\end{array}$ & $\begin{array}{c}-0.32^{* * *} \\
(0.12)\end{array}$ & $\begin{array}{c}-0.29^{* * *} \\
(0.11)\end{array}$ \\
\hline FDI $(-1)$ & $\begin{array}{l}0.04^{*} \\
(0.02)\end{array}$ & $\begin{array}{l}-0.01 \\
(0.01)\end{array}$ & $\begin{array}{c}0.05^{* *} \\
(0.02)\end{array}$ & $\begin{array}{c}0.01 \\
(0.09)\end{array}$ & $\begin{array}{l}-0.001 \\
(0.02)\end{array}$ & $\begin{array}{c}0.02 \\
(0.05)\end{array}$ \\
\hline FDI*Integration & $\begin{array}{l}-0.09 \\
(0.06)\end{array}$ & & & $\begin{array}{c}0.25 \\
(0.49)\end{array}$ & & \\
\hline FDI*Forward Integration & & $\begin{array}{c}0.15^{* *} \\
(0.06)\end{array}$ & & & $\begin{array}{l}0.19^{*} \\
(0.13)\end{array}$ & \\
\hline FDI*Backward Integration & & & $\begin{array}{l}-0.002 \\
(0.001)\end{array}$ & & & $\begin{array}{c}0.0003 \\
(0.002)\end{array}$ \\
\hline Fixed effects & Country & Country & Country & - & - & - \\
\hline No. of Observations & 2077 & 1828 & 1828 & 1938 & 1697 & 1697 \\
\hline No. of Groups & 179 & 160 & 160 & 175 & 156 & 156 \\
\hline 2nd Order Correlation ( $\mathrm{p}$-value) & - & - & - & 0.52 & 0,19 & 0,48 \\
\hline Hansen test ( $\mathrm{p}$-value) & - & - & - & 0.37 & 0,35 & 0,42 \\
\hline
\end{tabular}

Notes: All regressions include a constant term. Robust standard clustered errors corrected at country-industry level are reported. Asterisks $(*, * *, * * *)$ indicate the level of significance $(10 \%, 5 \%, 1 \%)$ of coefficients. 
variable, the value of the coefficient of output is larger (in absolute value) than in OLS estimates. The main change in IV estimates is that FDI outflows turn non-significant suggesting that the average effect of FDI on domestic investment is close to zero when the specification does not include any variable to proxy industry horizontal integration. The positive effect of the interaction with the forward vertical integration variable remains significant at $10 \%$ level pointing to a complementarity relationship between FDI abroad and domestic investment which is dependent on the intensity of industry forward linkages. When the forward integration indicator gets its maximum value, the effect of 1 percent points increase in FDI outflows is a 0.39 percantage increase in the change of rate of domestic investment. The highest median effects are to be found in the manufacturing industry which accounts for the highest forward linkages in most countries, as shown in figure 3 .

Figure 3: Effect of foreign investment on real investment growth (a)(b)

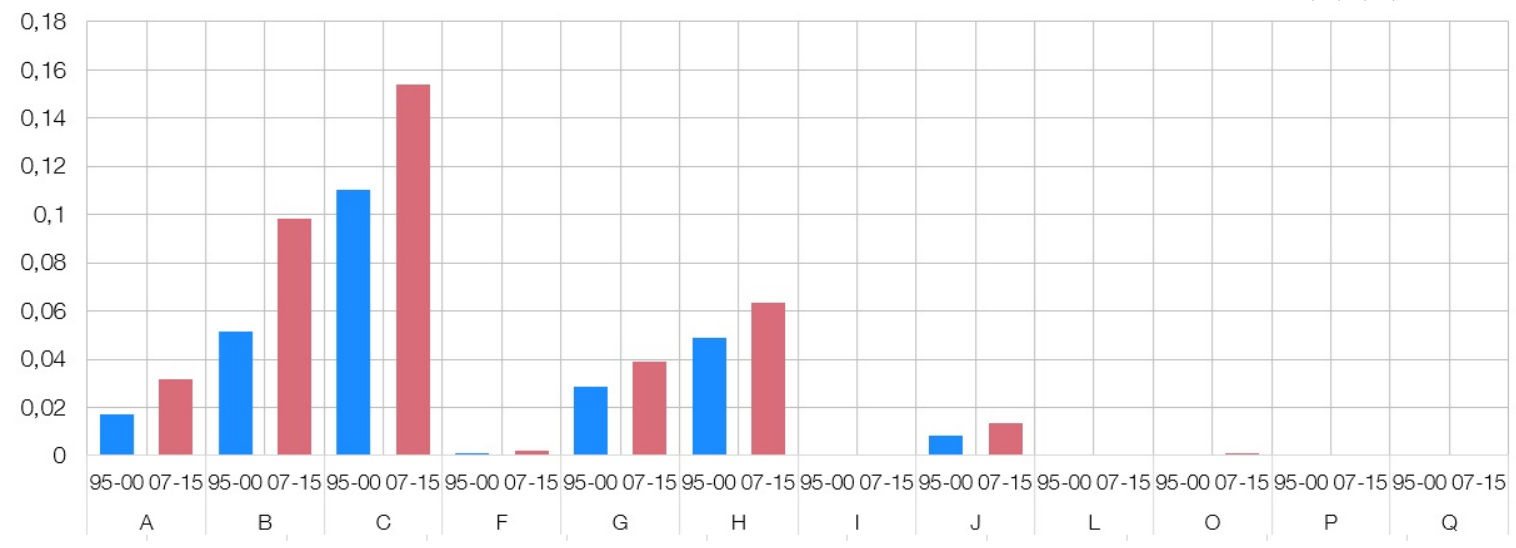

Source: Eurostat, OECD, own calculations.

(a) A: agriculture; B: mining; C: manufacturing industry; F: construction; G: retail; H: transport; I: hotels, restaurants; J: information, communication; L: real estate actitivities; O: public administration; P: education; Q: health, social work.

(b) Assesed at the median of the forward integration indicator for each sector.

\section{Robustness checks}

To assess the robustness of the previous results, several sensitivity tests are presented in this section. The first one is related to the presence of unobserved time-invariant differences across countries that may be related to labour market or other kind of institutional regulations. These possible missing factors are considered by including country fixed-effects in the baseline IV estimations displayed in column (2) of tables 3 and 4 . They did not appear to be significant when added to the horizontal integration baseline equation and, although some of them are significant, in the case of the vertical integration baseline estimation, the coefficients of the FDI variables (FDI and its interaction with horizontal and vertical indicators) are still significant and very similar in both cases. This suggests that the link between FDI and domestic investment is not affected by omitted time-invariant unobserved country-specific heterogeneity.

The neoclassical model we have used to select controls for our basic specification may not be adequate if the production process is not well captured by a production function with a 
constant elasticity of substitution. In that case the relative price of production factors is also relevant. Therefore, we test whether the relationship between FDI and domestic investment depends on the production technology specification by including an indicator of the cost of labour. The results, reported in columns (3) of tables 3 and 4, show that the link between FDI and investment remains significant and that the industry integration-FDI interactions maintains sign, negative for more horizontally integrated industries and positive for those vertically integrated industries with higher forward linkages.

Table 3: Robustness checks: horizontal integration

\begin{tabular}{|c|c|c|c|c|c|c|c|}
\hline & $(1)$ & $(2)$ & $(3)$ & $(4)$ & $(5)$ & $(6)$ & $(7)$ \\
\hline & IV & IV & IV & IV & IV & IV & IV \\
\hline \multicolumn{8}{|c|}{ Dependent variable: D.Real investment } \\
\hline D.log (Real investment (-1)) & $\begin{array}{c}-0.12^{* *} \\
(0.06)\end{array}$ & $\begin{array}{c}-0.11^{* *} \\
(0.06)\end{array}$ & $\begin{array}{c}-0.12^{* *} \\
(0.06)\end{array}$ & $\begin{array}{l}-0.12^{*} \\
(0.06)\end{array}$ & $\begin{array}{c}-0.15^{* *} \\
(0.06)\end{array}$ & $\begin{array}{c}-0.18^{* * *} \\
(0.06)\end{array}$ & $\begin{array}{c}-0.16^{* *} \\
(0.07)\end{array}$ \\
\hline D.log (Value added) & $\begin{array}{c}1.21^{* * *} \\
(0.26)\end{array}$ & $\begin{array}{c}1.21^{* * *} \\
(0.27)\end{array}$ & $\begin{array}{c}1.06 * * * \\
(0.20)\end{array}$ & $\begin{array}{c}1.12^{* * *} \\
(0.24)\end{array}$ & $\begin{array}{c}1.08^{* * *} \\
(0.29)\end{array}$ & $\begin{array}{l}0.64^{*} \\
(0.37)\end{array}$ & $\begin{array}{c}1.30^{* * *} \\
(0.30)\end{array}$ \\
\hline D.log (User cost of capital $(-1)$ ) & $\begin{array}{c}-0.26^{* * *} \\
(0.09)\end{array}$ & $\begin{array}{c}-0.26^{* * * *} \\
(0.09)\end{array}$ & $\begin{array}{c}-0.36^{* * *} \\
(0.13)\end{array}$ & $\begin{array}{c}-0.20 * * \\
(0.09)\end{array}$ & $\begin{array}{c}-0.27 * * * \\
(0.09)\end{array}$ & $\begin{array}{l}-0.06 \\
(0.09)\end{array}$ & $\begin{array}{c}-0.31^{* * * *} \\
(0.09)\end{array}$ \\
\hline FDI $(-1)$ & $\begin{array}{c}0.60^{* *} \\
(0.30)\end{array}$ & $\begin{array}{c}0.63^{* *} \\
(0.29)\end{array}$ & $\begin{array}{c}0.60^{* *} \\
(0.26)\end{array}$ & $\begin{array}{l}0.39^{*} \\
(0.23)\end{array}$ & $\begin{array}{c}0.59 * * \\
(0.29)\end{array}$ & $\begin{array}{c}0.36^{* *} \\
(0.18)\end{array}$ & $\begin{array}{c}0.69 * * \\
(0.33)\end{array}$ \\
\hline FDI*Intelectual property & $\begin{array}{c}-1.73^{* *} \\
(0.88)\end{array}$ & $\begin{array}{c}-1.84^{* *} \\
(0.88)\end{array}$ & $\begin{array}{c}-1.86^{* *} \\
(0.82)\end{array}$ & $\begin{array}{l}-1.18^{*} \\
(0.70)\end{array}$ & $\begin{array}{c}-1.77^{*} \\
(0.90)\end{array}$ & $\begin{array}{c}-0.89^{* *} \\
(0.44)\end{array}$ & $\begin{array}{c}-2.09^{*} \\
(1.10)\end{array}$ \\
\hline D.log (Wages $(-1)$ ) & & & $\begin{array}{l}0.24^{*} \\
(0.14)\end{array}$ & & & & \\
\hline Inward FDI $(-1)$ & & & & $\begin{array}{c}0.08 \\
(0.06) \\
\end{array}$ & & & \\
\hline Fixed effects & - & Country & - & - & - & - & - \\
\hline No. of Observations & 1719 & 1719 & 1719 & 1676 & 1380 & 1006 & 1162 \\
\hline No. of Groups & 144 & 144 & 144 & 143 & 118 & 140 & 142 \\
\hline 2nd Order Correlation (p-value) & 0.77 & 0.79 & 0.77 & 0.96 & 0.71 & 0.94 & 0.17 \\
\hline Hansen test (p-value) & 0.23 & 0.08 & 0.59 & 0.30 & 0.43 & 0.59 & 0.18 \\
\hline
\end{tabular}

Notes: All regressions include a constant term. Robust standard clustered errors corrected at country-industry level are reported. Asterisks $(*, * *, * * *)$ indicate the level of significance $(10 \%, 5 \%, 1 \%)$ of coefficients.

Domestic and outward foreign investment might also be reflecting the dynamics of foreign companies' investment in the country and therefore, non-consideration of FDI inflows in the model might lead to an omitted variable bias. So to avoid it, we include the inward FDI flows in our baseline estimations. Results are displayed in column (4) of tables 3 and 4 . There are no relevant changes in the estimates and FDI inflows seem to be not significant.

Another robustness check tries to assess how sensitive the basic model is to the inclusion of very particular industries such as manufacturing, where vertical integration is very widespread (in some cases in the form of global value chains), or real state. Fixed capital formation of this latter industry is determined by a set of economic factors different from the ones determining business investment ${ }^{19}$. The results obtained when both industries are excluded are reported in column (5) of tables 3 and 4 . They show that there is still a significant positive link between foreign and domestic investment and the interaction with the intangible intensity is still negative and significant. In the case of the vertical integration baseline equation, the positive relation between FDI inflows and domestic investment remains significant.

\footnotetext{
${ }^{19}$ Households' hourse purchases are included in this industry according to national accounts methodology.
} 
Table 4: Robustness checks: vertical integration

\begin{tabular}{|c|c|c|c|c|c|c|}
\hline & (1) & $(2)$ & (3) & (4) & $(5)$ & $(6)$ \\
\hline \multicolumn{7}{|l|}{ Dependent variable: D.Real investment } \\
\hline D.log (Real investment $(-1)$ ) & $\begin{array}{l}-0.11^{*} \\
(0.06)\end{array}$ & $\begin{array}{l}-0.06 \\
(0.07)\end{array}$ & $\begin{array}{c}-0.24^{* * *} \\
(0.09)\end{array}$ & $\begin{array}{l}-0.11 \\
(0.07)\end{array}$ & $\begin{array}{c}-0.13^{*} \\
(0.08)\end{array}$ & $\begin{array}{l}-0.02 \\
(0.09)\end{array}$ \\
\hline D.log (Real investment (-2)) & $\begin{array}{c}-0.10^{* *} \\
(0.04)\end{array}$ & $\begin{array}{c}-0.09^{* *} \\
(0.04)\end{array}$ & $\begin{array}{c}-0.13^{* * *} \\
(0.04)\end{array}$ & $\begin{array}{c}-0.10^{* *} \\
(0.04)\end{array}$ & $\begin{array}{l}-0.09^{*} \\
(0.05)\end{array}$ & $\begin{array}{c}-0.13^{* *} \\
(0.06)\end{array}$ \\
\hline D.log (Value added) & $\begin{array}{c}0.80^{* * *} \\
(0.16)\end{array}$ & $\begin{array}{c}0.90^{* * * *} \\
(0.19)\end{array}$ & $\begin{array}{c}0.81^{* * *} \\
(0.20)\end{array}$ & $\begin{array}{c}0.74^{* * *} \\
(0.19)\end{array}$ & $\begin{array}{c}0.86^{* * *} \\
(0.21)\end{array}$ & $\begin{array}{c}0.80^{* * * *} \\
(0.18)\end{array}$ \\
\hline D.log (User cost of capital $(-1)$ ) & $\begin{array}{c}-0.32^{* * *} \\
(0.12)\end{array}$ & $\begin{array}{c}-0.39 * * * \\
(0.13)\end{array}$ & $\begin{array}{c}-1.34^{* * *} \\
(0.38)\end{array}$ & $\begin{array}{c}-0.27^{* *} \\
(0.12)\end{array}$ & $\begin{array}{c}-0.20^{*} \\
(0.11)\end{array}$ & $\begin{array}{c}-0.22^{*} \\
(0.12)\end{array}$ \\
\hline FDI $(-1)$ & $\begin{array}{c}-0.001 \\
(0.02)\end{array}$ & $\begin{array}{l}0.005 \\
(0.02)\end{array}$ & $\begin{array}{l}0.005 \\
(0.06)\end{array}$ & $\begin{array}{l}-0.01 \\
(0.02)\end{array}$ & $\begin{array}{l}-0.01 \\
(0.02)\end{array}$ & $\begin{array}{l}0.006 \\
(0.02)\end{array}$ \\
\hline FDI*Forward Integration & $\begin{array}{l}0.19^{*} \\
(0.13)\end{array}$ & $\begin{array}{l}0.18^{*} \\
(0.11)\end{array}$ & $\begin{array}{l}0.23^{*} \\
(0.13)\end{array}$ & $\begin{array}{c}0.27^{* *} \\
(0.12)\end{array}$ & $\begin{array}{l}0.27^{*} \\
(0.16)\end{array}$ & $\begin{array}{c}0.21^{* *} \\
(0.09)\end{array}$ \\
\hline D.log (Wages $(-1)$ ) & & & $\begin{array}{c}1.02^{* * *} \\
(0.29)\end{array}$ & & & \\
\hline Inward FDI $(-1)$ & & & & $\begin{array}{l}-0.16 \\
(0.14)\end{array}$ & & \\
\hline Fixed effects & - & Country & - & - & - & - \\
\hline No. of Observations & 1697 & 1697 & 1547 & 1627 & 1274 & 1021 \\
\hline No. of Groups & 156 & 156 & 140 & 151 & 121 & 153 \\
\hline 2nd Order Correlation (p-value) & 0,19 & 0,31 & 0,12 & 0,12 & 0,15 & 0,22 \\
\hline Hansen test (p-value) & 0,35 & 0.19 & 0,23 & 0,36 & 0,15 & 0,16 \\
\hline
\end{tabular}

Notes: All regressions include a constant term. Robust standard clustered errors corrected at country-industry level are reported. Asterisks $\left(*, * *,{ }^{* *}\right)$ indicate the level of significance $(10 \%, 5 \%, 1 \%)$ of coefficients.

Last robustness checks explore the stability of the model when different time periods are considered: the first one covering the pre-crisis years and the second one much affected by the economic crisis period. In the pre-crisis period, the results, displayed in column (6) of table 3 for the horizontal integration analysis, show a positive and significant relation between FDI outflows and domestic investment, as well as a negative sign in the interaction term. Nevertheless, coefficients are smaller in magnitude and the user cost becomes not significant, probably reflecting measurement problems of the horizontal integration indicator in the first years of the sample and the dynamics of intangible assets, which were negligible in official statistics in the years before the 2000s. Estimations for the second period are shown in the last column of tables 3 and 4 for the preferred equations in our horizontal and vertical integration analyses, respectively. In these two cases, the basic results remain unchanged in terms of sign, size and significance.

\section{Concluding remarks}

The empirical results presented in this study show that the relationship between outward FDI and domestic investment is very varied and may differ across industries and across countries. That relationship is positive (complementarity) for those industries with high forward integration in GVCs or low intensity in intangible investment (features of vertically integrated industries), gets smaller as industries increase their share of intellectual property assets, and becomes negative in those industries with high intangible intensity (horizontally integrated). These results give support to the hypothesis that the vertical / horizontal integration of production predominant in each industry is one of the drivers that determine the type of relationship between FDI and gross fixed capital investment in home economies. Furthermore, the diversity of effects across industries may help to explain why firm and country studies 
-that do not usually consider the vertical /horizontal integration of production organisationhave been inconclusive when examining this relationship.

On average the complementarity relationship is predominant in most advanced economies. This highlights the potential of spillovers across countries by means of the FDI channel, which is especially relevant in areas closely connected through FDI links, as it is the case in the EU. These externalities call for a coordination to avoid barriers to trade and capital mobility, as well as for avoiding policies aimed at discouraging foreign investment. The complementarity between FDI and investment in home economies also help to explain, at least in some part, the synchronized weakness of investment observed in several advanced economies after the financial crisis.

The outlook of an increasing share of investment dedicated to intellectual property assets, which are prone to be used in different plants across several countries, leads us to expect an increasing pressure over firms to adopt a more horizontal organization of production across countries. A higher substitution of domestic investment for FDI thus appears likely. Against this perspective, policies should try to offset the potential negative impact on long run growth by favouring productivity-enhancing growth, as well as by mitigating the adjustment costs in home economies. 


\section{References}

Al-Sadig, A. J. (2013). Outward foreign direct investment and domestic investment: the case of developing countries. IMF Working Paper, WP/13/52.

Antràs, P. (2003). Firms, contracts, and trade structure. Quarterly Journal of Economics, Vol. 118 (4), 1375-1418.

Antràs, P., Chor, D., Fally, T., and Hillberry, R. (2012). Measuring the upstreamness of production and trade flows. The American Economic Review, Vol. 102, No. 3, 412-416.

Arellano, M. (1995). Another look at the instrumental variable esitmation of error-component models. Journal of Econometrics, No. 68, 29-52.

Arndt, C., Buch, C. M., and Schnitzer, M. E. (2010). FDI and domestic investment: an industry-level view. The B.E. Journal of Economic Analysis and Policy, De Gruyter, Vol. 10, Issue 1, 1-22.

Barba Navaretti, G., Castellani, D., and Disdier, A.-C. (2010). How does investing in cheap labour countries affect performance at home? France and Italy. Oxford Economic Papers, Vol. 62, No. 2, 234-260.

Bean, C. (1981). An econometric model of manufacturing investment in the UK. The Economic Journal, Vol. 91, 106-121.

Belderbos, R., Fukao, K., Ito, K., and Letterie, W. (2013). Global fixed capital investment by multinational firms. Economica, No. 80, 274-299.

Blundell, R. A. (1998). Initial conditions and moment restrictions in dynamic panel data models. Journal of Econometrics, No. 87, 115-143.

Braunerhjelm P., L. O. (2005). The relationship between domestic and outward foreign direct investment. International Busines Review, No. 14, 677-694.

Carr, D. L., Markusen, J. R., and Maskus, K. E. (2001). Estimating the knowledge-capital model of the multinational enterprise. The American Economic Review, Vol. 91, No. 3, 693-708.

Desai, M. A., Foley, C. F., and Hines Jr., J. R. (2005). Foreign Direct Investment and the Domestic Capital Stock. Cambridge, MA: National Bureau of Economic Research. 
Desai, M. A., Foley, C. F., and Hines Jr., J. R. (2009). Domestic effects of the foreign activities of US multinationals. American Economic Journal: Economic Policy, Vol.1, Issue 1, 181-203.

Faeth, I. (2006). Consequences of FDI in Australia-Casual Links Between FDI, Domestic Investment, Economic Growth and Trade. The University of Melbourne. Department of Economics. Research Paper No. 977.

Feldstein, M. (1995). The Effects of Outbound Foreign Direct Investment on the Domestic Capital Stock. In M. Feldstein, J. R. Hines Jr., and R. G. Hubbard, The Effects of Taxation on Multinational Corporations (pp. 43-66). University of Chicago Press.

Geishecker, I., and Görg, H. (2005). The vertical investment controversy: Re-estimating the knowledge-capital model for different types of FDI. U. of Nottingham Working Paper No. 2005-03.

Helpman, E. (2006). Trade, FDI, and the organization of firms. Journal of Economic Literature, Vol. 44, No. 3, 589-630.

Helpman, E., Melitz, M. J., and Yeaple, S. R. (2004). Export versus FDI with heterogeneous firms. American Economic Review, Vol. 94, Issue 1, 300-316.

Herzer, D., and Schrooten, M. (2008). Outward FDI and domestic investment in two industrialized countries. Economics Letters, Vol. 99, Issue 1, 139-143.

Jorgenson, D. (1963). Capital theory and investment behaviour. American Economic Review, vol 53, 247-56.

Koopman, R., Powers, W., Wang, Z., and Wei, S.-J. (2010). Give credit where credit is due: tracing value added in global production chains. Cambridge, MA: NBER Working Paper Series.

Markusen, J. R. (1995). The boundaries of multinational enterprises and the theory of international trade. The Journal of Economic Perspectives, Vol. 9, No. 2, 169-189.

Onaran, Ö., Stockhammer, E., and Zwickl, K. (2013). FDI and domestic investment in Germany: crowding in or out? International Review of Applied Economics. Vol. 27, Issue 4, 429-448.

Perry, M. K. (1989). Vertical integration: Determinants and effects. In R. S. Willig, Handbook of industrial organisation, Vol. 1. 
Stevens, G. V., and Lipsey, R. E. (1992). Interactions between domestic and foreign investment. Journal of International Money and Finance, Vol. 11, Issue 1, 40-62.

Wang, Z., Wei, S.-J., Yu, X., and Zhu, K. (2017). Measures of participation in global value chains and global business cycles. Cambridge, MA: NBER Working Paper Series.

Williamson, O. (1985). The Economic Institutions of Capitalism. New York: Free Press. 


\section{Statistical Appendix}

Table 1: Variable definition and sources

\begin{tabular}{|c|c|c|}
\hline Variable & Definition & Source \\
\hline Real domestic investment & Real gross fixed capital formation & $\begin{array}{l}\text { STAN Database for } \\
\text { Structural Analysis (ISIC } \\
\text { Rev. 4) (OECD) }\end{array}$ \\
\hline Value added & Real gross value added & $\begin{array}{l}\text { STAN Database for } \\
\text { Structural Analysis (ISIC } \\
\text { Rev. 4) (OECD) }\end{array}$ \\
\hline $\begin{array}{l}\text { Relative price of capital } \\
\text { goods }\end{array}$ & $\begin{array}{l}\text { Ratio of investment deflator over } \\
\text { gross value added deflator }\end{array}$ & $\begin{array}{l}\text { STAN Database for } \\
\text { Structural Analysis (ISIC } \\
\text { Rev. 4) (OECD) }\end{array}$ \\
\hline Real cost of finance & $\begin{array}{l}\text { Long term public debt interest rate } \\
\text { over gross value added deflator }\end{array}$ & $\begin{array}{l}\text { STAN Database for } \\
\text { Structural Analysis (ISIC } \\
\text { Rev. 4), Economic Out- } \\
\text { look Database (OECD) }\end{array}$ \\
\hline Corporate tax rate & $\begin{array}{l}\text { Corporate effective average tax } \\
\text { rate }\end{array}$ & $\begin{array}{l}\text { CBT Tax Database, Ox- } \\
\text { ford University Center for } \\
\text { Business Taxation }\end{array}$ \\
\hline $\begin{array}{l}\text { Foreign direct investment } \\
\text { (FDI) }\end{array}$ & $\begin{array}{l}\text { Ratio of outward foreign direct in- } \\
\text { vestment to gross value added }\end{array}$ & $\begin{array}{l}\text { FDI Statistics according } \\
\text { to BMD3 (OECD) }\end{array}$ \\
\hline $\begin{array}{l}\text { Intangible investment } \\
\text { share }\end{array}$ & $\begin{array}{l}\text { Ratio of intellectual property in- } \\
\text { vestment to total gross fixed in- } \\
\text { vestment }\end{array}$ & Eurostat \\
\hline Real wage & $\begin{array}{l}\text { Wage per employee over gross } \\
\text { value added deflator }\end{array}$ & $\begin{array}{l}\text { STAN Database for } \\
\text { Structural Analysis (ISIC } \\
\text { Rev. 4) (OECD) }\end{array}$ \\
\hline $\begin{array}{l}\text { Global Value Chain inte- } \\
\text { gration }\end{array}$ & $\begin{array}{l}\text { Domestic value added embodied in } \\
\text { foreign exports as a share of gross } \\
\text { exports (Forward integration indi- } \\
\text { cator) + Foreign value added share } \\
\text { of gross exports (Backward inte- } \\
\text { gration) }\end{array}$ & TiVA database (OECD) \\
\hline $\begin{array}{l}\text { Forward integration } \\
\text { Global Value Chains }\end{array}$ & $\begin{array}{l}\text { Gross exports of intermediates } \\
\text { over value added }\end{array}$ & TiVA database (OECD) \\
\hline $\begin{array}{l}\text { Backward integration in } \\
\text { Global Value Chains }\end{array}$ & $\begin{array}{l}\text { Gross imports of intermediates } \\
\text { over final production }\end{array}$ & TiVA database (OECD) \\
\hline
\end{tabular}

Table 2: Descriptive statistics

\begin{tabular}{lcccccccc}
\hline Variable & Obs & Mean & Std. Dev. & Min. & P25 & P50 & P75 & Max. \\
\hline D. $\log ($ Real investment) & 6402 & 0,023 & 0,179 & $-2,286$ & $-0,046$ & 0,028 & 0,099 & 2,362 \\
D. $\log$ (Value added) & 6574 & 0,018 & 0,061 & $-0,709$ & $-0,005$ & 0,018 & 0,045 & 0,466 \\
D.log(User cost of capital) & 5891 & $-0,017$ & 0,073 & $-0,602$ & $-0,045$ & $-0,015$ & 0,011 & 0,666 \\
FDI over gross value added & 2886 & 0,063 & 0,291 & $-1,181$ & 0,000 & 0,007 & 0,038 & 5,906 \\
Intelectual property share & 5177 & 0,194 & 0,264 & $-6,346$ & 0,042 & 0,110 & 0,301 & 10,050 \\
D.log(Wages) & 6021 & 0,019 & 0,078 & $-0,627$ & $-0,009$ & 0,018 & 0,050 & 0,660 \\
Integration & 4058 & 0,156 & 0,123 & 0,005 & 0,072 & 0,124 & 0,193 & 0,668 \\
Forward integration & 3783 & 0,166 & 0,270 & 0,000 & 0,001 & 0,022 & 0,215 & 2,027 \\
Backward integration & 3784 & 0,351 & 1,689 & 0,000 & 0,002 & 0,016 & 0,120 & 36,604 \\
\hline
\end{tabular}




\title{
BANCO DE ESPAÑA PUBLICATIONS
}

\author{
WORKING PAPERS
}

1830 JACOPO TIMINI and MARINA CONESA: Chinese exports and non-tariff measures: testing for heterogeneous effects at the product level.

1831 JAVIER ANDRÉS, JOSÉ E. BOSCÁ, JAVIER FERRI and CRISTINA FUENTES-ALBERO: Households' balance sheets and the effect of fiscal policy.

1832 ÓSCAR ARCE, MIGUEL GARCÍA-POSADA, SERGIO MAYORDOMO and STEVEN ONGENA: Adapting lending policies when negative interest rates hit banks' profits.

1833 VICENTE SALAS, LUCIO SAN JUAN and JAVIER VALLÉS: Corporate cost and profit shares in the euro area and the US: the same story?

1834 MARTÍN GONZÁLEZ-EIRAS and CARLOS SANZ: Women's representation in politics: voter bias, party bias, and electoral systems.

1835 MÓNICA CORREA-LÓPEZ and BEATRIZ DE BLAS: Faraway, so close! Technology diffusion and firm heterogeneity in the medium term cycle of advanced economies.

1836 JACOPO TIMINI: The margins of trade: market entry and sector spillovers, the case of Italy (1862-1913).

1837 HENRIQUE S. BASSO and OMAR RACHEDI: The young, the old, and the government: demographics and fiscal multipliers.

1838 PAU ROLDÁN and SONIA GILBUKH: Firm dynamics and pricing under customer capital accumulation.

1839 GUILHERME BANDEIRA, JORDI CABALLÉ and EUGENIA VELLA: Should I stay or should I go? Austerity, unemployment and migration.

1840 ALESSIO MORO and OMAR RACHEDI: The changing structure of government consumption spending.

1841 GERGELY GANICS, ATSUSHI INOUE and BARBARA ROSSI: Confidence intervals for bias and size distortion in IV and local projections - IV models.

1842 MARÍA GIL, JAVIER J. PÉREZ, A. JESÚS SÁNCHEZ and ALBERTO URTASUN: Nowcasting private consumption: traditional indicators, uncertainty measures, credit cards and some internet data.

1843 MATÍAS LAMAS and JAVIER MENCÍA: What drives sovereign debt portfolios of banks in a crisis context?

1844 MIGUEL ALMUNIA, POL ANTRÀS, DAVID LÓPEZ-RODRÍGUEZ and EDUARDO MORALES: Venting out: exports during a domestic slump.

1845 LUCA FORNARO and FEDERICA ROMEI: The paradox of global thrift.

1846 JUAN S. MORA-SANGUINETTI and MARTA MARTÍNEZ-MATUTE: An economic analysis of court fees: evidence from the Spanish civil jurisdiction.

1847 MIKEL BEDAYO, ÁNGEL ESTRADA and JESÚS SAURINA: Bank capital, lending booms, and busts. Evidence from Spain in the last 150 years.

1848 DANIEL DEJUÁN and CORINNA GHIRELLI: Policy uncertainty and investment in Spain.

1849 CRISTINA BARCELÓ and ERNESTO VILLANUEVA: The risk of job loss, household formation and housing demand: evidence from differences in severance payments.

1850 FEDERICO TAGLIATI: Welfare effects of an in-kind transfer program: evidence from Mexico.

1851 ÓSCAR ARCE, GALO NUÑO, DOMINIK THALER and CARLOS THOMAS: A large central bank balance sheet? Floor vs corridor systems in a New Keynesian environment.

1901 EDUARDO GUTIÉRREZ and ENRIQUE MORAL-BENITO: Trade and credit: revisiting the evidence.

1902 LAURENT CAVENAILE and PAU ROLDAN: Advertising, innovation and economic growth.

1903 DESISLAVA C. ANDREEVA and MIGUEL GARCÍA-POSADA: The impact of the ECB's targeted long-term refinancing operations on banks' lending policies: the role of competition.

1904 ANDREA ALBANESE, CORINNA GHIRELLI and MATTEO PICCHIO: Timed to say goodbye: does unemployment benefit eligibility affect worker layoffs?

1905 CORINNA GHIRELLI, MARÍA GIL, JAVIER J. PÉREZ and ALBERTO URTASUN: Measuring economic and economic policy uncertainty, and their macroeconomic effects: the case of Spain.

1906 CORINNA GHIRELLI, JAVIER J. PÉREZ and ALBERTO URTASUN: A new economic policy uncertainty index for Spain.

1907 ESTEBAN GARCÍA-MIRALLES, NEZIH GUNER and ROBERTO RAMOS: The Spanish personal income tax: facts and parametric estimates.

1908 SERGIO MAYORDOMO and OMAR RACHEDI: The China syndrome affects banks: the credit supply channel of foreign import competition. 
1909 MÓNICA CORREA-LÓPEZ, MATÍAS PACCE and KATHI SCHLEPPER: Exploring trend inflation dynamics in Euro Area countries.

1910 JAMES COSTAIN, ANTON NAKOV and BORJA PETIT: Monetary policy implications of state-dependent prices and wages.

1911 JAMES CLOYNE, CLODOMIRO FERREIRA, MAREN FROEMEL and PAOLO SURICO: Monetary policy, corporate finance and investment.

1912 CHRISTIAN CASTRO and JORGE E. GALÁN: Drivers of productivity in the Spanish banking sector: recent evidence.

1913 SUSANA PÁRRAGA RODRÍGUEZ: The effects of pension-related policies on household spending.

1914 MÁXIMO CAMACHO, MARÍA DOLORES GADEA and ANA GÓMEZ LOSCOS: A new approach to dating the reference cycle.

1915 LAURA HOSPIDO, LUC LAEVEN and ANA LAMO: The gender promotion gap: evidence from Central Banking.

1916 PABLO AGUILAR, STEPHAN FAHR, EDDIE GERBA and SAMUEL HURTADO: Quest for robust optimal macroprudential policy.

1917 CARMEN BROTO and MATÍAS LAMAS: Is market liquidity less resilient after the financial crisis? Evidence for US treasuries.

1918 LAURA HOSPIDO and CARLOS SANZ: Gender Gaps in the Evaluation of Research: Evidence from Submissions to Economics Conferences.

1919 SAKI BIGIO, GALO NUÑO and JUAN PASSADORE: A framework for debt-maturity management.

1920 LUIS J. ÁLVAREZ, MARÍA DOLORES GADEA and ANA GÓMEZ-LOSCOS: Inflation interdependence in advanced economies.

1921 DIEGO BODAS, JUAN R. GARCÍA LÓPEZ, JUAN MURILLO ARIAS, MATÍAS J. PACCE, TOMASA RODRIGO LÓPEZ, JUAN DE DIOS ROMERO PALOP, PEP RUIZ DE AGUIRRE, CAMILO A. ULLOA and HERIBERT VALERO LAPAZ: Measuring retail trade using card transactional data.

1922 MARIO ALLOZA and CARLOS SANZ: Jobs multipliers: evidence from a large fiscal stimulus in Spain.

1923 KATARZYNA BUDNIK, MASSIMILIANO AFFINITO, GAIA BARBIC, SAIFFEDINE BEN HADJ, ÉDOUARD CHRÉTIEN, HANS DEWACHTER, CLARA ISABEL GONZÁLEZ, JENNY HU, LAURI JANTUNEN, RAMONA JIMBOREAN, OTSO MANNINEN, RICARDO MARTINHO, JAVIER MENCÍA, ELENA MOUSARRI, LAURYNAS NARUŠEVIČIUS, GIULIO NICOLETTI, MICHAEL O'GRADY, SELCUK OZSAHIN, ANA REGINA PEREIRA, JAIRO RIVERA-ROZO, CONSTANTINOS TRIKOUPIS, FABRIZIO VENDITTI and SOFÍA VELASCO: The benefits and costs of adjusting bank capitalisation: evidence from Euro Area countries.

1924 MIGUEL ALMUNIA and DAVID LÓPEZ-RODRÍGUEZ: The elasticity of taxable income in Spain: 1999-2014.

1925 DANILO LEIVA-LEON and LORENZO DUCTOR: Fluctuations in global macro volatility.

1926 JEF BOECKX, MAARTEN DOSSCHE, ALESSANDRO GALESI, BORIS HOFMANN and GERT PEERSMAN: Do SVARs with sign restrictions not identify unconventional monetary policy shocks?

1927 DANIEL DEJUÁN and JUAN S. MORA-SANGUINETTI: Quality of enforcement and investment decisions. Firm-level evidence from Spain.

1928 MARIO IZQUIERDO, ENRIQUE MORAL-BENITO and ELVIRA PRADES: Propagation of sector-specific shocks within Spain and other countries.

1929 MIGUEL CASARES, LUCA DEIDDA and JOSÉ E. GALDÓN-SÁNCHEZ: On financial frictions and firm market power.

1930 MICHAEL FUNKE, DANILO LEIVA-LEON and ANDREW TSANG: Mapping China's time-varying house price landscape.

1931 JORGE E. GALÁN and MATÍAS LAMAS: Beyond the LTV ratio: new macroprudential lessons from Spain.

1932 JACOPO TIMINI: Staying dry on Spanish wine: the rejection of the 1905 Spanish-Italian trade agreement.

1933 TERESA SASTRE and LAURA HERAS RECUERO: Domestic and foreign investment in advanced economies. The role of industry integration.

BANCODEESPAÑA

Eurosistema
Unidad de Servicios Auxiliares

Alcalá, 48 - 28014 Madrid

E-mail: publicaciones@bde.es www.bde.es 